\title{
Protein misfolding in neurodegenerative diseases: implications and strategies
}

\author{
Patrick Sweeney ${ }^{1,2^{*}}$, Hyunsun Park ${ }^{3}$, Marc Baumann ${ }^{4}$, John Dunlop ${ }^{5}$, Judith Frydman ${ }^{6}$, Ron Kopito ${ }^{6}$, \\ Alexander McCampbell', Gabrielle Leblanc ${ }^{8}$, Anjli Venkateswaran ${ }^{1}$, Antti Nurmi ${ }^{1}$ and Robert Hodgson ${ }^{1}$
}

\begin{abstract}
A hallmark of neurodegenerative proteinopathies is the formation of misfolded protein aggregates that cause cellular toxicity and contribute to cellular proteostatic collapse. Therapeutic options are currently being explored that target different steps in the production and processing of proteins implicated in neurodegenerative disease, including synthesis, chaperone-assisted folding and trafficking, and degradation via the proteasome and autophagy pathways. Other therapies, like mTOR inhibitors and activators of the heat shock response, can rebalance the entire proteostatic network. However, there are major challenges that impact the development of novel therapies, including incomplete knowledge of druggable disease targets and their mechanism of action as well as a lack of biomarkers to monitor disease progression and therapeutic response. A notable development is the creation of collaborative ecosystems that include patients, clinicians, basic and translational researchers, foundations and regulatory agencies to promote scientific rigor and clinical data to accelerate the development of therapies that prevent, reverse or delay the progression of neurodegenerative proteinopathies.
\end{abstract}

Keywords: Neurodegeneration, Proteostasis, Mouse models, Biomarkers, Chaperones, Drug discovery

\section{Background}

Many neurodegenerative diseases involve the misfolding and aggregation of specific proteins into abnormal, toxic species. Therapeutic targeting of protein misfolding has generated unique challenges for drug discovery and development for several reasons, including 1) the dynamic nature of the protein species involved, 2) uncertainty about which forms of a given disease protein (monomers, oligomers, or insoluble aggregates) are primarily responsible for cellular toxicity, 3) our still limited understanding about which components of the cellular proteostatic machinery these disease proteins interact with and 4) lack of well-validated biomarkers for clinical trials. However, as we continue to gain knowledge of disease mechanisms, improve our abilities to model disease states in vitro and in vivo, and identify new biomarkers, there is increasing optimism that we will discover novel therapeutics that prevent, reverse, or delay the progression of neurodegenerative diseases. In concert with the

\footnotetext{
* Correspondence: patrick.sweeney@crl.com

'Discovery Services, Charles Rivers Laboratories, Wilmington, MA, USA

${ }^{2}$ Royal Veterinary College, University of London, London, UK

Full list of author information is available at the end of the article
}

scientific advances in the past several decades, the field of neurodegenerative disease research is undergoing significant change with respect to how various stakeholders engage each other and share information with the entire community. Increasing collaboration between scientists from the pharmaceutical industry disease foundations, academic researchers, contract research organizations, and patient advocacy group, and increasing communication between groups studying different diseases, has spurred promising initiatives in basic, translational, and clinical research in neurodegenerative disease.

There are multiple steps in the production and processing of disease proteins that could be targeted therapeutically, from initial synthesis to degradation and extracellular clearance (Fig. 1). This review discusses the advantages and potential problems associated with targeting different pathways involved in the production and processing of misfolded proteins, and highlights new candidate therapeutics that have been developed by targeting specific steps in the life cycles of disease proteins. It also discusses some key issues involved in translating preclinical findings to successful clinical trials ${ }^{1}$. 


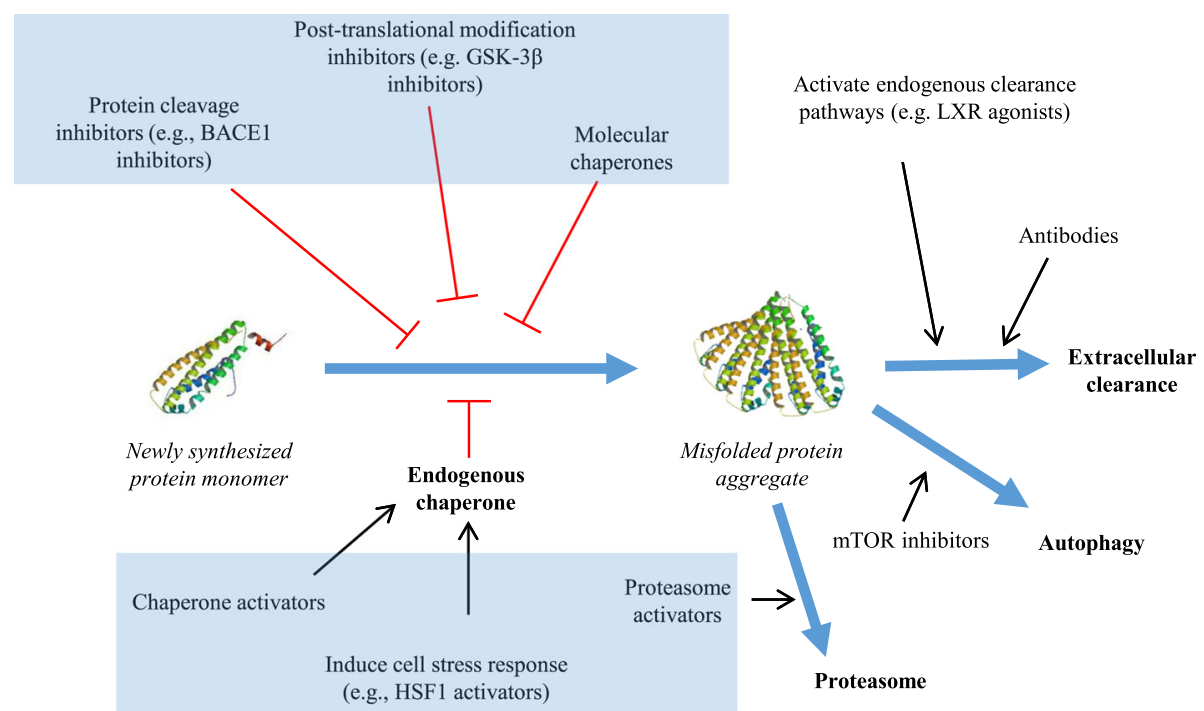

Fig. 1 Mechanisms involved in protein misfolding \& therapeutic targets. A newly synthesized protein is stabilized by endogenous chaperone proteins. Under normal conditions abnormal protein aggregates (misfolded proteins) are degraded and/or cleared extracellularly, undergo autophagy or are degraded with the aid of the cellular proteasome. In cases of abnormality and misfolding of proteins (such as those present in many neurological diseases) post translational modification inhibitors, protein cleavage inhibitors and extrinsic molecular chaperones have been used in attempts to curtail or correct protein misfolding. In addition, post translational approaches to address and combat the presence of misfolded proteins include agonists that attempt to activate endogenous clearance pathways as well as the introduction of recombinant antibodies to work against the rogue protein

\section{Roles of misfolded proteins and aggregates in proteinopathies}

Misfolded proteins exist in cells together with unfolded, intermediately folded, and correctly folded species [1]. In healthy cells, misfolded proteins are either degraded or refolded correctly by chaperone proteins that are involved in protein folding and trafficking as well as intermediate stabilization [1]. Indeed, it is now believed that many, if not all, proteins can form amyloid fibrils under appropriate biochemical conditions [2, 3]. However, many disease-associated amyloidogenic proteins have extensive regions of intrinsic disorder in their free soluble forms [4] and have specific, often short, internal amino acid sequences that are necessary and sufficient to support aggregation $[3,5]$. These same motifs can be found in other non-disease proteins, and when liberated from rest of protein these fragments will aggregate into cytotoxic amyloid fibrils $[2,5]$.

Once formed, higher order amyloid aggregates are highly resistant to degradation. Proteasomes can degrade only single chain polypeptides, and also require the proteins to be partially or fully (in the case of proteasomes) unfolded [6]. In addition, the amyloid state is extremely stable thermodynamically, because of the extensive contacts made between the protein chains of the polymer. The thermodynamic stability of amyloid aggregates also contributes to their ability to convert native proteins into amyloid forms (i.e., to seed prion-like propagation) [7].
Under conditions of proteotoxic stress, cellular aging, or the presence of disease mutations, proteins can escape a cell's quality control system and begin to aggregate into non-native structures, which range from oligomers and amorphous assemblies to highly ordered amyloid fibrils and plaques.

Cells are normally faced with a continuous stream of misfolded proteins arising from mistakes in biogenesis, disease-causing mutations, and physiological stressors (Table 1 lists misfolded proteins associated with neurodegenerative disease). They deal with misfolded proteins by refolding, degrading, or sequestering them in specific intracellular compartments, such as aggresomes or other types of inclusion bodies. Chaperone proteins bind to nascent polypeptides as they emerge from ribosomes

Table 1 Misfolded proteins associated with neurodegenerative diseases

\begin{tabular}{ll}
\hline Proteinopathy & Aggregating protein(s) \\
\hline Alzheimer's disease & Amyloid beta (Ab) peptide; Tau \\
Parkinson's disease & a-synuclein \\
Multiple tauopathies & Tau protein (microtubule associated) \\
Huntington's disease & $\begin{array}{l}\text { Huntingtin with tandem glutamine } \\
\text { repeats }\end{array}$ \\
Amyotrophic lateral sclerosis & Superoxide dismutase 1 \\
Spongiform encephalopathies & Prion proteins \\
Familial amyloidotic & Transthyretin (mutant forms) \\
polyneuropathy & \\
\hline
\end{tabular}


and assist in their folding, and oversee and participate in every step in the handling of misfolded proteins. Chaperones also monitor the quality of the folded chains and can in some cases unfold and refold misfolded proteins. Alternatively, chaperones target the misfolded proteins for degradation via the ubiquitin proteasome system or autophagy pathway, or for sequestration in various cellular compartments $[8,9]$.

Studies in yeast have revealed two overlapping but functionally distinct networks of chaperones $[10,11]$. CLIPs (chaperones linked to protein synthesis) are physically associated with the translational machinery and oversee quality control of newly translated proteins. CLIPs comprise a large family of proteins, and evidence suggests that different CLIPs associate with different classes of proteins [12]. The second set of chaperones, heat shock proteins (HSPs), protects the proteome from denaturing environmental stressors, including thermal, oxidative, and hypoxic stresses. CLIPs and HSPs have different modes of transcriptional regulation in yeast: CLIPs are generally down-regulated under conditions of proteotoxic stress, whereas HSPs are up-regulated [9, 10]. Subnetworks of differentially regulated chaperones and co-chaperones have also been identified in C. elegans and in the human brain [13]. In addition, it has been found that as the human brain ages, a subset of chaperones consisting primarily of CLIPs are repressed, and chaperones that help protect the proteome against misfolded protein toxicity are induced mimicking proteotoxic stress; these differences are even more pronounced in the brains of people with Alzheimer's, Huntington's, or Parkinson's disease [13]. Misfolded proteins that are not immediately refolded are actively sequestered in spatially and functionally segregated quality control compartments $[8,14]$. In yeast, the juxtanuclear quality control (JUNQ) compartment concentrates soluble misfolded proteins that are either later refolded by chaperones or degraded by the ubiquitin proteasome system (UPS). The insoluble protein deposit (IPOD) compartment, which may be equivalent to the aggresomes found in mammalian cells, sequesters insoluble aggregates. The sequestration of aggregated misfolded proteins may in many cases serve a beneficial role - by preventing misfolded proteins from saturating chaperones and proteasomes, facilitating their clearance via the UPS or through autophagy, or by preserving them for subsequent refolding and return to use in the cell $[15,16]$.

\section{Proteostasis}

The term "proteostasis" refers to the integrated activity of cellular mechanisms that regulate protein production, folding, trafficking, degradation, and clearance. Cellular responses to proteotoxic stress, like the heat shock response and the unfolded protein response (UPR) involve large-scale rebalancing of the proteostatic network via transcriptional regulation of both chaperones (e.g., Hsp70, Hsp90) and non-chaperone proteins (including transcription factors, signaling proteins and receptors, and cell cycle regulators [17]. Post-translational modifications can also radically change the activity of some chaperones [18], and likely also play a key role in proteostasis, although this area remains largely unexplored. During the ageing process, or in diseases associated with misfolded proteins, cells may experience "proteostatic collapse." Proteostatic collapse is associated with the accumulation of ubiquitinated inclusion bodies (IBs), which are seen in many neurodegenerative diseases [9]. It has been suggested that ubiquitinated aggregates can directly inhibit or clog proteasomes $[19,20]$. However, in the case of ubiquitinated Huntingtin (Htt), this does not appear to be the case, nor is ubiquitination required for Htt to accumulate in IBs [21]. Rather, the accumulation of ubiquitinated species in misfolded protein diseases may reflect a global perturbation of proteostasis, in which chaperones and proteasomes are simply overwhelmed with client proteins.

\section{Propagation}

A key feature of misfolded protein diseases is the ability of the pathogenic protein species to propagate in a prion-like manner by recruiting normally folded counterparts to adopt pathogenic conformations. Pathogenic amyloids can also spread from neurons to other neurons and neighboring glia to initiate new pathology after injection into the brains of normal animals [22, 23]. Both in vivo and in vitro studies have shown that misfolding of one disease causing protein can induce misfolding of other aggregation-prone proteins [23], and aggregates of different disease proteins may be found in the same patient [24]. Moreover, the accumulation of one species of misfolded proteins can impair the entire proteostatic network, thereby triggering the misfolding of unrelated proteins that would otherwise fold normally [25, 26]. The mechanisms by which misfolded proteins spread from one neuron to another are currently an area of active investigation. New evidence suggests that interneuronal spread of misfolded proteins involves 1) activity-dependent secretion by exosomes ([27] and/or 2) chaperone-mediated pathways $[28,29]$.

\section{Mechanisms of misfolded protein toxicity}

In the long term, all neurodegenerative disease proteins produce synaptic dysfunction and loss and, ultimately, neuronal cell death. The precise upstream mechanisms by which different misfolded disease proteins cause neurotoxicity are still unclear, and appear to differ depending on the protein species involved. Misfolded disease proteins appear to act primarily by toxic gain-offunction and/or dominant-negative effects, although 
loss-of-function effects have also been observed. Direct, acute effects of misfolded proteins on neuronal function have been observed after treating neurons with purified oligomers or transfecting them with expression vectors. To give just a few examples, amyloid-beta, tau, and alphasynuclein all interfere with synaptic signaling [30-32]; mutant tau disrupts microtubule function and neuronal transport mechanisms [32, 33]; and alpha-synuclein disrupts mitochondrial protein import [32, 34]. In addition, larger aggregates of misfolded proteins may exert toxic effects by binding to and sequestering other cytosolic proteins. For example, proteomic studies of artificial proteins designed to form amyloid-like fibrils showed that the toxicity of these proteins correlated with the ability of their aggregates to engage in aberrant protein interactions and disrupt the cytosolic stress response [35]. Notably, the endogenous cellular proteins sequestered by the amyloid aggregates tended to be relatively large in size and enriched in intrinsically unstructured regions, and many play key roles in essential cellular activities such as transcription, translation and protein quality control. Indeed, another emerging common feature among misfolded disease proteins is their ability to disrupt proteostasis (see more below). More recently, cytosolic aggregates of several different proteins, including artificial $\beta$-sheets, fragments of mutant huntingtin, and TAR DNA binding protein- 43 (TDP-43) have also been shown to disrupt nucleocytoplasmic transport of both proteins and RNA [36].

In addition to synaptic dysfunction, other cellular changes common to the major neurodegenerative diseases include calcium signaling abnormalities, mitochondrial dysfunction, oxidative stress, and neuroinflammation. These symptoms of cellular distress often occur early in the disease process, and are believed to be a cause as well as a consequence of neurodegeneration. That is, the relationship between the accumulation of misfolded disease proteins and other signs of cellular distress is bidirectional, and in many cases mutually exacerbating. For example, amyloid- $\beta$, a-synuclein, and $\mathrm{mHtt}$ all cause acute oxidative stress in neurons and/or astrocytes, and impair astroglial anti-oxidant responses [37-40]. Conversely, oxidative stress promotes the aggregation of disease proteins, and contributes to age- and disease-related proteostatic collapse [41, 42]. Similarly, there appearaas a downward spiralling cycle of interactions between protein misfolding and neuroinflammation, which has been most extensively studied for AD. Soluble $A \beta$ oligomers and insoluble $A \beta$ aggregates have been shown to bind to and activate and microglia and astrocytes, stimulating a chronic low level state of neuroinflammation [43]. Several lines of evidence suggest that the pro-inflammatory effects of $A \beta$, while perhaps helpful in the short-term, ultimately impair the microglial and astroglial function, including their ability to dispose of $A \beta$ and other misfolded proteins [38, 43-45].
The destructive consequences of the neuroinflammation provoked by misfolded disease proteins are likely exacerbated by ongoing, age-related senescence of the immune system senescence $[46,47]$.

\section{Therapeutic targets}

Targeting production, misfolding and aggregation

The development of drugs targeting protein misfolding or aggregation has been challenging due to the lack of certainty about which form/s of a given disease protein is primarily responsible for the disease. In the case of amyloid- $\beta(A \beta)$, it was originally thought that fibrils and plaques were the pathogenic species in Alzheimer's disease, but more recent studies point to aggregation intermediates (oligomers and soluble protofibrils) as the primary culprits; similar findings have emerged with respect to different species of $\alpha$-synuclein in Parkinson's disease $[4,48]$. The situation is further complicated by the existence of the variety of intermediate species that exist during the folding and oligomerization processes. Recent studies have demonstrated that aggregated fibrils of tau, $\alpha$-synuclein, and $A \beta$ exist in different conformational variants, or 'strains', that have different propagation properties and different levels of neurotoxicity [49-51].

Identifying key toxic species of misfolded proteins has been challenged the inability of conventional biochemical analytic methods to detect and characterize intermediate species. For example, denaturing gel electrophoresis (SDS-PAGE) has been shown to alter the oligomerization state of A 342 oligomers [52]. Recently, ion mobility spectrometry-mass spectrometry (IMS-MS) and nuclear magnetic resonance (NMR) spectroscopy have been used to analyze the folding and aggregation of amyloid proteins in solution and to identify inhibitors of these processes [53-55]. As an alternative to preventing the initial misfolding and aggregation of amyloids, another approach now being explored is to stabilize mature fibrils to prevent their prion-like propagation $[48,56]$.

In cases where the relative pathogenicity of various misfolded protein species is unknown, one strategy would be to intervene therapeutically as far upstream as possible in the protein synthesis pathway: i.e., at the level of protein translation, cleavage, or posttranslational modification. In theory, targeting early steps in the processing pathway would provide the highest degree of therapeutic specificity and eliminate toxic gains or losses of function caused by misfolded or aggregated forms of the protein, while preventing the propagation of abnormal folding and aggregation. Protein cleavage and post-translational modification targets are being actively explored for $A \beta$ using Beta Amyloid Cleaving Enzyme (BACE) inhibitors (some of which are now in clinical trials) and for tau using 
inhibitors of tau phosphorylation (e.g., glycogen synthase $3 \beta$ inhibitors) and acetylation [57-60].

\section{Targeting chaperones}

Chaperones are another possible target class for therapeutic intervention in protein misfolding disease states. As chaperones are involved in all aspects of proteostasis, they offer potential therapeutic entry points to each step in the processing of a pathogenic protein. There are over 200 different chaperone proteins expressed in the mammalian brain [61], and different cell types express different sets of chaperones and co-chaperones [62, 63]. Cell type-specific expression of chaperone subsets may help to explain why some misfolded proteins are toxic in one cell type and not in others, and also presents opportunities to develop drugs targeting neuron- or glial cellspecific chaperones. However, the sheer number of chaperones and the diversity in their mechanisms of action also presents challenge to therapeutics development; we still have limited knowledge of which chaperones interact with which disease proteins and how. Some clues have been offered by links between mutations in specific chaperones and hereditary forms of certain neurodegenerative diseases. For example, mutations in Hsp70 and Hsp40 have been linked to Parkinson's disease [64, 65], and mutations in the cochaperone valosin-containing protein (VCP) have been found in ALS [66]. In addition, to date over 20 different chaperones have been found to confer neuroprotection when over-expressed in cell or animal models of various neurodegenerative diseases, and in many cases individual chaperones appear to protect against several different disease proteins [67].

One approach to therapeutically targeting the chaperone system has been to develop small molecule inhibitors or activators of specific chaperones. Among chaperones relevant to neurodegeneration, Hsp70 and Hsp90 have been the most intensely studied. Hsp70 and Hsp90 have opposing effects on client protein stability: Hsp70 promotes their degradation via the UPS system, whereas Hsp90 stabilizes client proteins and inhibits their ubiquitination. The activities of Hsp90 and Hsp70 are tightly linked via HSF1. Hsp90 inhibitors typically activate HSF1, which in turn induces Hsp70 [68]. A variety of small molecule drugs have been developed that inhibit Hsp90, activate Hsp70, or both, and have been shown to reduce the formation of disease protein aggregates, reduce cellular toxicity, and improve neurological phenotypes in cellular and animal models of SBMA, HD, $\mathrm{PD}$, and $\mathrm{AD}[62,67,69-71]$. None of these drugs have yet entered clinical trials for use in neurodegenerative diseases, due to issues of low brain penetration and/or peripheral cytotoxicity, but active effort in this area is continuing [70, 72-74].
A second approach to developing chaperone-based therapeutics has been through protein engineering. For example, it was discovered that the yeast disaggregate Hsp104 has the ability to dissolve in vitro fibrils formed from a variety of neurodegenerative disease proteins, including tau, polyglutamine, $\mathrm{A} \beta 42, \alpha$-synuclein and prion protein $[75,76]$. However, relatively high concentrations of Hsp104 are needed to dissolve these proteins. Making small changes in Hsp104's sequence yielded proteins with much higher dissaggregase activity and lower toxicity, including variants that reduced neurodegeneration in a C. elegans model of PD [77]. Other chaperones to which this approach might be applied include the yeast chaperonin Tric, which has the unusual ability to cross cell membranes and has been shown to protect against Htt toxicity [16], and metazoan chaperones known to have disaggregase activity (e.g., Hsp110, Hsp70, and Hsp40) [78].

\section{Targeting degradation}

Defects in both the UPS and autophagy pathways of protein degradation are often seen in neurodegenerative diseases $[79,80]$. For example, many of the gene mutations that cause familial PD encode proteins involved in the UPS and/or autophagy, including PINK-1, Parkin (a ubiquitin ligase), UCH-L1 (Ub carboxy terminal hydrolase L1), DJ-1 (PARK7), and LRRK2/PRAK8 [79, 81, 82]. As with the chaperone system, choosing promising drug targets from the UPS or autophagy pathways is challenging because of the number of proteins involved (there are $\sim 500$ to 1000 associated just with the UPS system). In addition, for most diseases it isn't known which form/ $\mathrm{s}$ of the disease protein are primarily responsible for cellular toxicity. This issue is critical when targeting protein degradation, because the pathway by which a given protein is degraded (e.g., UPS versus autophagy) can vary depending on whether the protein is in the soluble or fibrillar state, and on what specific post-translational modifications it bears $[83,84]$.

A number of small molecules have been identified that upregulate components of the UPS, promote the degradation of disease proteins and in vitro, and (in some cases) have neuroprotective effects on cultured cells [84-86], but few have yet been shown to be effective in vivo. One interesting exception is rolipram, an agent that stimulates the phosphorylation and activity of the $26 \mathrm{~S}$ proteasome. Myeku and colleagues [21] showed that 26S proteasome function is impaired in a mouse tauopathy model, and that treating the mice with rolipram treatment improved 26S proteasome function, decreased tau aggregation, and improved cognition.

Inhibition of the mammalian target of rapamycin (mTOR) pathway has proven to be an exceptionally effective approach for stimulating the degradation of 
neurodegenerative disease proteins. mTOR, a serine/ threonine kinase, is a signaling nexus that collects information about ambient levels of resources necessary for cell growth (e.g., nutrients, ATP, growth factors, and oxygen) and up- or downregulates protein synthesis and degradation accordingly. When growth conditions are favorable, mTOR inhibits autophagy by inhibiting the ULK1 complex, which is required for the biogenesis of autophagosomes. Thus, mTOR inhibitors typically have the net effect of stimulating autophagy [87, 88].

Rapamycin and other mTOR inhibitors increase the clearance of abnormal protein aggregates and slow neurodegeneration in both cell and animal models of a variety of neurodegenerative diseases, including $\mathrm{AD}, \mathrm{PD}$, spinocerebellar ataxia type 3 , and frontotemporal dementia $[87,88]$. In most of these cases, mTOR inhibitors have been shown to act at least in part via stimulation of autophagy. A recent study showed that in yeast, inhibiting mTOR also produces a rapid, coordinated upregulation of proteasomes and their $19 \mathrm{~S}$ regulatory chaperones [89]. Thus, the efficacy of mTOR inhibitors in clearing a variety of neurodegenerative disease proteins may be due to the ability of these drugs to upregulate both the proteasomal and autophagic routes of protein degradation.

Several mTOR-dependent activators of autophagy, including the natural compounds curcurmin and resveratrol, are currently in clinical trials for treating neurodegenerative diseases. However, mTOR is a multifarious protein that regulates many cellular processes in addition to protein degradation, and in clinical trials to date wmTOR inhibitors have caused unpredictable and undesirable side effects. Autophagy can be stimulated mTOR-independent mechanisms $[79,87,88]$, and a number of compounds, including FDA-approved drugs, have now been shown to stimulate clearance of abnormal proteins and confer protective effects in cell or animal models of neurodegenerative disease $[87,88,90,91]$. It has been suggested that these compounds might be used in conjuction with mTOR inhibitors to maximize therapeutic benefit and minimize side effects [87, 90].

\section{Targeting extracellular clearance}

One of the best-explored examples of targeting clearance of misfolded proteins has been the use of antibodies to promote clearance of $A \beta$. These antibodies are thought to operate by either or both of two mechanisms: 1) by penetrating the blood brain barrier (BBB) to bind $A \beta$ in the extracellular space, and 2) through a"peripheral sink" effect [92]. Almost all misfolded proteins show some extracellular leakage [93], and an advantage of targeting extracellular misfolded proteins is that it can theoretically be accomplished by highly selective antibodies. For example, monoclonal antibodies have been developed to $\mathrm{A} \beta$ and $\alpha$-synuclein that show $>1000$-fold higher affinities for the oligomeric versus monomeric forms of the proteins [94-96].

Current challenges in the use of $A \beta$ antibodies include low rates of $\mathrm{BBB}$ penetration [97], nonspecific engagement of $A \beta$ and uncertainty as to which antibodies engage clinically relevant forms of $A \beta$ [98-100]. Detailed structural studies of how different antibodies interact with specific epitopes in the $A \beta$ molecule are now underway [101] and help inform antibody design and epitope-targeting in the future. An alternative method of improving the clearance of toxic misfolded species is to harness endogenous mechanisms of protein clearance into the extracellular space. For example, LXR beta receptor agonists, which promote clearance of $A \beta$ into the extracellular space by the ABCA1 transporter, have shown therapeutic effects in AD mouse models [102, 103]. Yet another potential avenue for new therapies targeting extracellular clearance of disease proteins is the use of non-antibody scaffold drugs [104].

\section{Rebalancing the proteostatic network}

The ability of the cell's proteostatic machinery to counter proteotoxic stressors deteriorates with age, and is further compromised by mutations and other disease conditions that lead to the accumulation of misfolded proteins [16]. Thus, another potential approach to the development of therapeutics would involve large-scale rebalancing of the proteostatic network. Indeed, the efficacy of mTOR inhibitors may reflect their ability to provoke large-scale rebalancing of protein synthesis and degradation pathways. Another attractive target in this regard is heat shock factor 1 (HSF1), a transcriptional activator that helps coordinate the heat shock response. The heat shock response (and other proteotoxic stress responses) diminish with age and in neurodegenerative disease [105]. In addition, it was recently shown that HSF1 degradation is abnormally elevated in mouse and human $\alpha$-synucleinopathy [106]. Over-expression of human HSF1 has been shown to be neuroprotective in cell models of neurodegenerative diseases $[107,108]$, to reduce polyglutamine aggregate formation and prolong lifespan in a mouse model of HD [17] and to reduce pathogenic androgen receptor accumulation and neurotoxicity in a mouse model of spinobulbar muscular atrophy [109]. Small molecule activators of HSF1 have now been identified and shown to have neuroprotective effects in cell or animal models of neurodegenerative diseases [107, 108].

Agents targeting HSF1 or other master regulators of the proteostatic network have the advantages of being fast-acting and relatively agnostic to the identities of the misfolded proteins involved in a given neurodegenerative 
disease and to their mechanisms of aggregation and toxicity. The effects of such drugs are hard to predict, however. For example, the induction of the heat shock response actually exacerbates Htt IB formation in a cellular model of HD [110]. In addition, it has been pointed out that, under normal physiological conditions, the heat shock response and other proteotoxic stress response pathways are activated only transiently, and that multiple cellular mechanisms are in place to limit and downregulate these responses [111]. Consistent with those facts, an Hsp90 inhibitor that induces the heat shock response in HD model mice was found to provide shortterm beneficial effects, but those benefits proved transient [112]. Yet another potential issue with HSF1 activators is that HSF1 promotes tumorigenesis and is activated in a broad range of highly malignant human cancers $[113,114]$. This issue is not necessarily unsurmountable, however, as it has also been shown that the HSF1 drives a different transcriptional program and stimulates different sets of cellular processes in cancer cells (including proliferation, invasion, and metastasis) than it does in normal cells [113]. The ability of HSF1 to activate distinct transcriptional programs in cancer cells versus normal cells is thought to result in part from differences in posttranscriptional modifications to HSF1 in the different cell types $[113,114]$, which in turn raises the possibility that the neuroprotective effects of HSF1 could be harnessed separately from its tumorigenic ones.

\section{Challenges in translating preclinical findings to clinical trials for diseases associated with misfolded proteins}

The misfolded protein neuropathies have proven an exceptionally challenging arena for therapeutics development. Promising candidates for Alzheimer's disease, Parkinson's disease, ALS, and Huntington's disease have been identified in preclinical studies, but very few have shown significant benefits in clinical trials (Table 2 lists known drug-target interactions for neurodegenerative diseases associated with misfolded proteins). This "failure to translate" has plagued the development of therapeutics for neurological diseases in general, and likely reasons for it have been discussed in detail elsewhere [115-117]. A leading cause is the lack of robust targets whose modulation results in a therapeutic benefit. The uncertainties about which process or protein to target, and resulting failures to demonstrate target engagement, result in preclinical studies in animal models that do not have predictive validity. Additionally, there is a strong need to identify translatable biomarkers in animal models for clinical studies. Finally, pharmacokinetics and drug safety pose significant challenges to successful drug development for misfolded protein diseases. Recently, however, strides have been made in the area of Alzheimer's disease with structural studies of how antibodies interact with specific epitopes on the amyloid- $\beta$ molecule, and how these interactions correlate with clinical outcomes [101].

Another area of opportunity is the identification of novel targets. For example, the area of cell typespecific targets has been relatively unexplored. A key feature of the proteinopathies is that the proteins involved are typically expressed in many or all cell types, but cause pathological phenotypes only in specific sets of neurons. Thus, informed development of therapeutics should include understanding not only of the species of misfolded proteins involved, but also of how they affect different populations of neurons. A recent genomic/proteomic study in HD model mice identified striatum- and cortex-specific transcription modules whose expression correlated strongly with both CAG repeat length and age [118]. Interestingly, striatal modules included genes involved in establishing and maintaining medium spiny neuron identity. Another study showed that the degeneration of different subtypes of neurons (e.g. striatal versus motor

Table 2 Drug-target pairs for neurodegenerative diseases associated with misfolded proteins

\begin{tabular}{|c|c|c|c|c|}
\hline Compound name & Company & Disease indication & Mechanism of action & Status \\
\hline TRx0237 & TauRx Therapeutics & Alzheimer's disease & Tau aggregation inhibitor & $\begin{array}{l}\text { Phase II clinical trials } \\
\text { completed }\end{array}$ \\
\hline AADvac1 & Axon Neuroscience SE & Alzheimer's disease & $\begin{array}{l}\text { Active tau based } \\
\text { immunotherapy }\end{array}$ & $\begin{array}{l}\text { Phase I clinical trials } \\
\text { completed }\end{array}$ \\
\hline $\mathrm{ACl}-35$ & AC Immune AG & Alzheimer's disease & Phospho-tau vaccine & Phase I trial active \\
\hline Arimoclomol & Orphazyme ApS & $\begin{array}{l}\text { Amyotrophic Lateral } \\
\text { Sclerosis }\end{array}$ & HSP activation & Phase $\|/\| I I$ active \\
\hline Nuedexta & $\begin{array}{l}\text { Avanir } \\
\text { Pharmaceuticals }\end{array}$ & $\begin{array}{l}\text { Amyotrophic Lateral } \\
\text { Sclerosis - PBA symptom } \\
\text { treatment }\end{array}$ & $\begin{array}{l}\text { Unknown for PBA treatment; } \\
\text { NMDA receptor antagonist }\end{array}$ & FDA approved \\
\hline Deferiprone & Generic & Parkinson's disease & Iron chelator & Phase II recruiting \\
\hline Istradefylline & Kyowa Hakko Kirin & Parkinson's disease & $\begin{array}{l}\text { Adenosine A2A receptor } \\
\text { antagonist }\end{array}$ & $\begin{array}{l}\text { Approved in Japan; } \\
\text { no FDA approval }\end{array}$ \\
\hline
\end{tabular}


neurons) is mediated by down-regulation of different sets of ER chaperones [119].

The use of transgenic rodent models to study pathogenic mechanisms presents more challenges in the case of the proteinopathies than in other diseases. The selection of the correct transgenic protein target is essential to develop a useful rodent model of overexpression. Transgenic models of disease are developed on the assumption that increased production of a particular protein drives disease development. When the correct protein target is not selected, the model does not accurately represent the pathogenic mechanism. Rodents differ from humans with respect to basic biology (i.e., glia to neuron ratio, anatomy of the brain vasculature) and the biochemical properties of misfolded disease protein aggregates [120]. A potential solution to the latter issue would be the use of human/mouse chimeras. For example, it has been shown that mutant huntingtinexpressing human glial precursor cells can impart the HD disease phenotype when grafted into the striata of normal mice, and that normal glial precursors can rescue certain phenotypes and slow disease progression when grafted into R6/2 HD mice [121].

Finally, there is a need for translatable biomarkers that robustly track the progression and severity of the disease for successful clinical trial. One approach has been to measure amounts of soluble disease protein in the cerebrospinal fluid (CSF). When analyzing soluble proteins, the stability and kinetics of protein turnover in the CSF must be established, along with inter- and intra-subject variability. A challenge with the use of soluble proteins as CSF biomarkers is their low concentrations in the CSF, which in turn produces a low signal-to-noise ratio. A new approach has been to study other components of the CSF, such as exosomes. Exosomes are released by most cell types, and carry cargoes of proteins that include misfolded disease proteins [122]. For chaperone or proteasome targets, which are intracellular, it may be necessary to develop surrogate markers to assess target engagement.

Molecular imaging approaches (e.g., positron emission tomography, or PET) are an alternate approach to assessing target distribution and engagement. Currently, direct imaging of neurodegenerative disease proteins in vivo is possible in humans only for amyloid and tau [123-125]. Most of the currently available amyloid PET ligands are limited in their utility because they bind only to insoluble fibrillar amyloid. Similarly, the development of tau tracers has challenged by the biochemical complexity and heterogeneity of tau deposits. Several promising tau tracers are now available for use in humans, but remain to be fully characterized with respect to their binding to specific isoforms and conformations of tau; in addition, all show significant off-target binding. The recent development of antibody-based PET ligands offers a potential solution to these issues. Such ligands have now been used to detect oligomeric $A \beta$ in the mouse brain and this approach might also be used for $\alpha$ synuclein and other neurodegenerative disease proteins for which no ligands are currently available [126].

A key issue that has arisen with respect to translatable biomarkers is lack of correlation between levels of disease proteins and functional outcomes in rodent models. For example, unlike humans, mouse $\mathrm{AD}$ models and some mouse HD models do not show neuronal cell death. However, even models that don't show cell death do typically show neuronal dysfunction and synaptic loss. Imaging ligands that demonstrate synaptic loss are now being developed in humans, and could be reversetranslated for use in rodent studies [127]. Alternative translatable measures of neuronal function currently being explored include EEG [128] and functional imaging markers [129].

\section{Collaborating to accelerate therapeutic development}

Until recently, drug discovery was the almost exclusive domain of biotechnology and pharmaceutical companies. Today, a new model for drug discovery has evolved, spurred in large part by initiatives led by patient advocacy groups, philanthropic organizations, the National Institutes of Health and other international funding agencies. This new model involves coordinated collaborations between academia, industry, private foundations, and government funding agencies, and incorporates patients and caregivers as key collaborators, knowledge resources, and decision-makers. Private foundations are increasingly taking on leadership roles that used to be handled primarily by government agencies, including the facilitation and scientific management of focused research initiatives, large-scale research consortia, and partnerships between academia, industry, and CROs.

Team approaches are particularly critical for the proteinopathies because of the heterogeneity and/or rarity of these conditions and the difficulty of recruiting sufficiently large patient cohorts for clinical trials for genetic disease. Patient advocacy groups and foundations are now playing critical roles in forcing some degree of standardization and scientific rigor, and providing critical natural history data for disease progression markers. Examples of such efforts include the Michael J. Fox Foundation Parkinson's Progression Markers Initiative, the Target ALS drug discovery program, the Alzheimer's disease Drug Discovery Foundation Access program, and the CHDI Foundation Preclinical Research program. Another key role for both governmental agencies and private foundations in supporting collaborations is through the development of public databases and "knowledge 
centers," such as the National Alzheimer's Coordinating Center and the Academic Drug Discovery Consortium. Recent national and international government initiatives supporting early drug discovery include the NIH Blueprint Neurotherapeutics Network and the European Innovative Medicines Initiative.

\section{Conclusion}

There is active research ongoing to uncover the mechanisms by which disease-associated proteins misfold, aggregate, and cause cellular toxicity. Continued progress in our ability to interrogate amyloid-forming proteins and their interactions with other cellular proteins provide confidence that novel therapies will be identified for multiple disease states. Therapeutic options now being explored include targeting misfolded protein-chaperone interactions at various points in the proteostatic pathway, promoting protein clearance, and large-scale rebalancing of proteostatic network. However, the identification and in vivo validation of new therapeutic compounds is impeded by the shortage of known disease drivers and the lack of reliable biomarkers for monitoring therapeutic responses in relevant animal models. However, the increase in cooperative research and collaboration among the drug discovery community (pharmaceutical companies, foundations, academia, contract research organizations, clinicians, regulatory agencies, advocacy groups and patients) is a positive shift that can help accelerate the identification of novel therapeutic modalities.

\section{Endnotes}

${ }^{1}$ This review is based in part on an open scientific satellite symposium entitled "Protein Misfolding - Implications and Strategies" held in conjunction with the $45^{\text {th }}$ Annual Society for Neuroscience meeting in 2015, sponsored and organized by Charles River Laboratories. The meeting panelists included: Hyunsun Park (Health \& Life Science Consulting), Judith Frydman (Stanford University), John Dunlop (Astra Zeneca), Marc Baumann (University of Helsinki), Alexander McCampbell (Biogen), Ron Kopito (Stanford University), Patrick Sweeney (Royal Veterinary College, University of London, Charles River Laboratories) and Robert Hodgson (Charles River Laboratories).

\footnotetext{
Abbreviations

AD: Alzheimer's disease; ALS: Amyotrophic lateral sclerosis; A 3 : Beta amyloid; BACE: Beta amyloid cleaving enzyme; BBB: Blood brain barrier; CLIP: Chaperones linked to protein synthesis; CRO: Contract research organization; CSF: Cerebrospinal fluid; DNA: Deoxyribonucleic acid; GFP: Green fluorescent protein; HSP: Heat shock proteins; Htt: Ubiquitinated Huntingtin; IMS: Ion mobility spectrometry; IMS-MS: Ion mobility spectrometry-mass spectrometry; IPOD: Insoluble protein deposit; JUNQ: Juxtanuclear quality control; MS: Mass spectrometry; mTOR: Mammalian target of rapamycin; NIH: National Institutes of Health; NMR: Nuclear magnetic resonance; SDS-PAGE: Denaturing gel
}

electrophoresis; TDP-43: TAR DNA binding protein-43; UPR: Unfolded protein response; UPS: Ubiquitin proteasome system; VCP: Valosin-containing protein VCP

\section{Acknowledgements}

Not applicable.

\section{Funding}

The consortium of thought leaders from industry and academia that was the primary content source for the manuscript was funded by Charles River Laboratories. G. Leblanc (Bioscience Consulting, Berkeley, CA) is a paid consultant of Charles River Laboratories to provide scientific and writing assistance.

\section{Availability of data and materials}

Data sharing not applicable to this article as no datasets were generated or analyzed during the current study.

\section{Authors' contributions}

PS conceived of the study, organized the consortium and revised the manuscript. HP moderated the consortium and reviewed the manuscript. MB, $J D, J F, R K$ and AM presented at the consortium and reviewed the manuscript. $\mathrm{GL}$ and $\mathrm{AV}$ drafted and reviewed the manuscript. $\mathrm{RH}$ co-organized the consortium and reviewed the manuscript. AN reviewed the manuscript. All authors read and approved the final manuscript.

\section{Competing interests}

The authors declare that they have no competing interests.

\section{Consent for publication}

Not applicable.

\section{Ethics approval and consent to participate}

Not applicable.

\section{Publisher's Note}

Springer Nature remains neutral with regard to jurisdictional claims in published maps and institutional affiliations.

\section{Author details}

${ }^{1}$ Discovery Services, Charles Rivers Laboratories, Wilmington, MA, USA. ${ }^{2}$ Royal Veterinary College, University of London, London, UK. ${ }^{3}$ Health \& Life Science Consulting, Los Angeles, CA, USA. ${ }^{4}$ Biochemistry and Developmental Biology, University of Helsinki, Helsinki, Finland. ${ }^{5}$ Neuroscience Innovation Medicines, Astra Zeneca, Cambridge, MA, USA. ${ }^{6}$ Stanford University, Stanford, CA, USA. ${ }^{7}$ Neurology, Biogen Idec, Cambridge, MA, USA. ${ }^{8}$ Leblanc Bioscience Consulting, Berkeley, CA, USA.

Received: 25 January 2017 Accepted: 1 March 2017

Published online: 13 March 2017

\section{References}

1. Hartl FU, Hayer-Hartl M. Converging concepts of protein folding in vitro and in vivo. Nat Struct Mol Biol. 2009;16:574-81. doi:10.1038/nsmb.1591.

2. Guijarro JI, Sunde M, Jones JA, Campbell ID, Dobson CM. Amyloid fibril formation by an SH3 domain. Proc Natl Acad Sci U S A. 1998;95:4224-8.

3. Tzotzos S, Doig AJ. Amyloidogenic sequences in native protein structures. Protein Sci. 2010;19:327-48. doi:10.1002/pro.314.

4. Knowles TP, Vendruscolo M, Dobson CM. The amyloid state and its association with protein misfolding diseases. Nature reviews. Mol Cell Biol. 2014;15:384-96. doi:10.1038/nrm3810.

5. Kallijarvi J, Haltia M, Baumann MH. Amphoterin includes a sequence motif which is homologous to the Alzheimer's beta-amyloid peptide (Abeta), forms amyloid fibrils in vitro, and binds avidly to Abeta. Biochemistry. 2001; 40:10032-7.

6. Finley D. Recognition and processing of ubiquitin-protein conjugates by the proteasome. Annu Rev Biochem. 2009;78:477-513.

7. Brundin P, Melki R, Kopito R. Prion-like transmission of protein aggregates in neurodegenerative diseases. Nat Rev Mol Cell Biol. 2010;11(4):301-7. doi:10. 1038/nrm2873. 
8. Chen B, Retzlaff M, Roos T, Frydman J. Cellular strategies of protein quality control. Cold Spring Harb Perspect Biol. 2011;3:a004374. doi:10.1101/ cshperspect.a004374.

9. Hipp MS, Park SH, Hartl FU. Proteostasis impairment in protein-misfolding and -aggregation diseases. Trends Cell Biol. 2014;24:506-14. doi:10.1016/j. tcb.2014.05.003.

10. Albanese V, Yam AY, Baughman J, Parnot C, Frydman J. Systems analyses reveal two chaperone networks with distinct functions in eukaryotic cells. Cell. 2006;124:75-88. doi:10.1016/j.cell.2005.11.039.

11. Albanese V, Reissmann S, Frydman J. A ribosome-anchored chaperone network that facilitates eukaryotic ribosome biogenesis. J Cell Biol. 2010;189: 69-81. doi:10.1083/jcb.201001054

12. del Alamo M, Hogan DJ, Pechmann S, Albanese V, Brown PO, Frydman J. Defining the specificity of cotranslationally acting chaperones by systematic analysis of mRNAs associated with ribosome-nascent chain complexes. PLoS Biol. 2011;9, e1001100. doi:10.1371/journal.pbio.1001100.

13. Brehme M, Voisine C, Rolland T, Wachi S, Soper JH, Zhu Y, Orton K, Villella A, Garza D, Vidal M, Ge H, Morimoto Rl. A chaperome subnetwork safeguards proteostasis in aging and neurodegenerative disease. Cell Rep. 2014;9:1135-50. doi:10.1016/j.celrep.2014.09.042.

14. Kaganovich D, Kopito R, Frydman J. Misfolded proteins partition between two distinct quality control compartments. Nature. 2008;454:1088-95. doi:10. 1038/nature07195.

15. Escusa-Toret S, Vonk WI, Frydman J. Spatial sequestration of misfolded proteins by a dynamic chaperone pathway enhances cellular fitness during stress. Nat Cell Biol. 2013;15:1231-43. doi:10.1038/ncb2838.

16. Sontag EM, Vonk WI, Frydman J. Sorting out the trash: the spatial nature of eukaryotic protein quality control. Curr Opin Cell Biol. 2014;26:139-46. doi: 10.1016/j.ceb.2013.12.006.

17. Hayashida N, Fujimoto M, Tan K, Prakasam R, Shinkawa T, Li L, Ichikawa H, Takii R, Nakai A. Heat shock factor 1 ameliorates proteotoxicity in cooperation with the transcription factor NFAT. EMBO J. 2010;29(20):3459-69. doi:10.1038/emboj.2010.225

18. Mollapour M, Neckers L. Post-translational modifications of Hsp90 and their contributions to chaperone regulation. Biochim Biophys Acta. 1823;2012: 648-55. doi:10.1016/j.bbamcr.2011.07.018.

19. Hipp MS, Patel CN, Bersuker K, Riley BE, Kaiser SE, Shaler TA, Brandeis M, Kopito RR. Indirect inhibition of 265 proteasome activity in a cellular model of Huntington's disease. J Cell Biol. 2012;196:573-87. doi:10.1083/jcb. 201110093.

20. Nonaka T, Hasegawa M. A cellular model to monitor proteasome dysfunction by alpha-synuclein. Biochemistry. 2009;48(33):8014-22. doi:10. 1021/bi900619j.

21. Myeku N, Clelland CL, Emrani S, Kukushkin NV, Yu WH, Goldberg AL, Duff KE. Tau-driven 265 proteasome impairment and cognitive dysfunction can be prevented early in disease by activating CAMP-PKA signaling. Nat Med. 2016;22:46-53. doi:10.1038/nm.4011.

22. Pearce MM, Spartz EJ, Hong W, Luo L, Kopito RR. Prion-like transmission of neuronal huntingtin aggregates to phagocytic glia in the Drosophila brain. Nat Commun. 2015;6:6768. doi:10.1038/ncomms7768.

23. Brettschneider J, Del Tredici K, Lee VM, Trojanowski JQ. Spreading of pathology in neurodegenerative diseases: a focus on human studies. Nat Rev Neurosci. 2015;16:109-20. doi:10.1038/nrn3887.

24. Galpern WR, Lang AE. Interface between tauopathies and synucleinopathies: a tale of two proteins. Ann Neurol. 2006;59(3):449-58. doi:10.1002/ana. 20819.

25. Gidalevitz T, Ben-Zvi A, Ho KH, Brignull HR, Morimoto Rl. Progressive disruption of cellular protein folding in models of polyglutamine diseases. Science. 2006;311:1471-4. doi:10.1126/science.1124514.

26. Gidalevitz T, Krupinski T, Garcia S, Morimoto RI. Destabilizing protein polymorphisms in the genetic background direct phenotypic expression of mutant SOD1 toxicity. PLoS Genet. 2009;5, e1000399. doi:10.1371/journal. pgen. 1000399.

27. Wu JW, Hussaini SA, Bastille IM, Rodriguez GA, Mrejeru A, Rilett K, Sanders DW, Cook C, Fu H, Boonen RA, Herman M, Nahmani E, Emrani S, Figueroa YH, Diamond MI, Clelland CL, Wray S, Duff KE. Neuronal activity enhances tau propagation and tau pathology in vivo. Nat Neurosci. 2016;19(8):1085-92. doi:10.1038/nn.4328.

28. Fontaine SN, Zheng D, Sabbagh JJ, Martin MD, Chaput D, Darling A, Trotter JH, Stothert AR, Nordhues BA, Lussier A, Baker J, Shelton L, Kahn M, Blair L, Stevens Jr SM, Dickey CA. DnaJ/Hsc70 chaperone complexes control the extracellular release of neurodegenerative-associated proteins. EMBO J. 2016;35(14):1537-49. doi:10.15252/embj.201593489.

29. Lee JG, Takahama S, Zhang G, Tomarev SI, Ye Y. Unconventional secretion of misfolded proteins promotes adaptation to proteasome dysfunction in mammalian cells. Nat Cell Biol. 2016;18(7):765-76. doi:10.1038/ncb3372.

30. Shankar GM, Li S, Mehta TH, Garcia-Munoz A, Shepardson NE, Smith I, Brett FM, Farrell MA, Rowan MJ, Lemere CA, Regan CM, Walsh DM, Sabatini BL, Selkoe DJ. Amyloid-beta protein dimers isolated directly from Alzheimer's brains impair synaptic plasticity and memory. Nat Med. 2008;14(8):837-42. doi:10.1038/nm1782.

31. Kopeikina KJ, Hyman BT, Spires-Jones TL. Soluble forms of tau are toxic in Alzheimer's disease. Transl Neurosci. 2012;3(3):223-33.

32. Ingelsson M. Alpha-Synuclein Oligomers-Neurotoxic Molecules in Parkinson's Disease and Other Lewy Body Disorders. Front Neurosci. 2016; 10:408. doi:10.3389/fnins.2016.00408.

33. Thies E, Mandelkow EM. Missorting of tau in neurons causes degeneration of synapses that can be rescued by the kinase MARK2/Par-1. J Neurosci. 2007;27(11):2896-907.

34. Di Maio R, Barrett PJ, Hoffman EK, Barrett CW, Zharikov A, Borah A, Hu X, McCoy J, Chu CT, Burton EA, Hastings TG, Greenamyre JT. a-Synuclein binds to TOM20 and inhibits mitochondrial protein import in Parkinson's disease. Sci Transl Med. 2016;8(342):342ra78. doi:10.1126/scitransImed.aaf3634.

35. Olzscha H, Schermann SM, Woerner AC, Pinkert S, Hecht MH, Tartaglia GG, Vendruscolo M, Hayer-Hartl M, Hartl FU, Vabular RM. Amyloid-like aggregates sequester numerous metastable proteins with essential cellular functions. Cell. 2011;144:67-78. doi:10.1016/j.cell.2010.11.050.

36. Woerner AC, Frottin F, Hornburg D, Feng LR, Meissner F, Patra M, Tatzelt J, Mann M, Winklhofer KF, Hartl FU, Hipp MS. Cytoplasmic protein aggregates interfere with nucleocytoplasmic transport of protein and RNA. Science. 2016;351(6269):173-6. doi:10.1126/science.aad2033.

37. Majd S, Power JH, Grantham HJ. Neuronal response in Alzheimer's and Parkinson's disease: the effect of toxic proteins on intracellular pathways. BMC Neurosci. 2015;16:69. doi:10.1186/s12868-015-0211-1.

38. Ben Haim L, Carrillo-de Sauvage MA, Ceyzériat K. Escartin C Elusive roles for reactive astrocytes in neurodegenerative diseases. Front Cell Neurosci. 2015; 9:278. doi:10.3389/fncel.2015.00278.

39. Jiang T, Sun Q, Chen S. Oxidative stress: A major pathogenesis and potential therapeutic target of antioxidative agents in Parkinson's disease and Alzheimer's disease. Prog Neurobiol. 2016;147:1-19. doi:10.1016/j.pneurobio. 2016.07.005.

40. Angelova PR, Abramov AY. Alpha-synuclein and beta-amyloid - different targets, same players: calcium, free radicals and mitochondria in the mechanism of neurodegeneration. Biochem Biophys Res Commun. 2017; 483(4):1110-5. doi:10.1016/j.bbrc.2016.07.103.

41. Taylor RC, Dillin A. Aging as an Event of Proteostasis Collapse. Cold Spring Harb Perspect Biol. 2011;3(5):a004440. doi:10.1101/cshperspect.a004440.

42. Höhn A, Weber D, Jung T, Ott C, Hugo M, Kochlik B, Kehm R, König J, Grune T, Castro JP. Happily (n)ever after: Aging in the context of oxidative stress, proteostasis loss and cellular senescence. Redox Biol. 2016;11:482-501. doi: 10.1016/j.redox.2016.12.001

43. Heppner FL, Ransohoff RM, Becher B. Immune attack: the role of inflammation in Alzheimer disease. Nat Rev Neurosci. 2015;16(6):358-72. do: 10.1038/nrn3880.

44. Chakrabarty P, Li A, Ceballos-Diaz C, Eddy JA, Funk CC, Moore B, DiNunno N Rosario AM, Cruz PE, Verbeeck C, Sacino A, Nix S, Janus C, Price ND, Das P, Golde TE. IL-10 alters immunoproteostasis in APP mice, increasing plaque burden and worsening cognitive behavior. Neuron. 2015;85(3):519-33. doi: 10.1016/j.neuron.2014.11.020.

45. Guillot-Sestier MV, Doty KR, Gate D, Rodriguez Jr J, Leung BP, Rezai-Zadeh K, Town T. II10 deficiency rebalances innate immunity to mitigate Alzheimerlike pathology. Neuron. 2015;85(3):534-48. doi:10.1016/..neuron.2014.12.068.

46. Deleidi $\mathrm{M}$, Jäggle $\mathrm{M}$, Rubino $\mathrm{G}$. Immune aging, dysmetabolism, and inflammation in neurological diseases. Front Neurosci. 2015;9:172. doi:10. 3389/fnins.2015.00172.

47. Currais A, Fischer W, Maher P, Schubert D. Intraneuronal protein aggregation as a trigger for inflammation and neurodegeneration in the aging brain. FASEB J. 2017;31(1):5-10. doi:10.1096/fj.201601184.

48. Lam HT, Graber MC, Gentry KA, Bieschke J. Stabilization of alphaSynuclein Fibril Clusters Prevents Fragmentation and Reduces Seeding Activity and Toxicity. Biochemistry. 2016;55(5):675-85. doi:10.1021/acs. biochem.5b01168. 
49. Guo JL, Covell DJ, Daniels JP, Iba M, Stieber A, Zhang B, Riddle DM, Kwong LK, Xu Y, Trojanowski JQ, Lee VM. Distinct alpha-synuclein strains differentially promote tau inclusions in neurons. Cell. 2013;154:103-17. doi: 10.1016/j.cell.2013.05.057

50. Sanders DW, Kaufman SK, DeVos SL, Sharma AM, Mirbaha H, Li A, Barker SJ, Foley AC, Thorpe JR, Serpell LC, Miller TM, Grinberg LT, Seeley WW, Diamond MI. Distinct tau prion strains propagate in cells and mice and define different tauopathies. Neuron. 2014;82:1271-88. doi:10.1016/j.neuron.2014.04.047.

51. Heilbronner G, Eisele YS, Langer F, Kaeser SA, Novotny R, Nagaratinam A, Aslund A, Hammarstrom P, Nilsson KP, Jucker M. Seeded strain-like transmission of beta-amyloid morphotypes in APP transgenic mice. EMBO Rep. 2013;14:1017-22. doi:10.1038/embor.2013.137.

52. Pujol-Pina R, Vilaprinyo-Pascual S, Mazzucato R, Arcella A, Vilaseca M, Orozco M, Carulla N. SDS-PAGE analysis of Abeta oligomers is disserving research into Alzheimer s disease: appealing for ESI-IM-MS. Scientific reports. 2015;5: 14809. doi:10.1038/srep14809.

53. Woods LA, Platt GW, Hellewell AL, Hewitt EW, Homans SW, Ashcroft AE, Radford SE. Ligand binding to distinct states diverts aggregation of an amyloid-forming protein. Nat Chem Biol. 2011;7:730-9. doi:10.1038/ nchembio.635.

54. Bleiholder C, Do TD, Wu C, Economou NJ, Bernstein SS, BUratto SK, Shea JE, Bowers MT. Ion mobility spectrometry reveals the mechanism of amyloid formation of Abeta (25-35) and its modulation by inhibitors at the molecular level: epigallocatechin gallate and scyllo-inositol. J Am Chem Soc. 2013;135:16926-37. doi:10.1021/ja406197f.

55. Neudecker P, Robustelli P, Cavalli A, Walsh P, Lundstrom P, Zarrine-Afsar A, Sharpe $S$, Vendruscolo M, Kay LE. Structure of an intermediate state in protein folding and aggregation. Science. 2012;336:362-6. doi:10.1126/ science.1214203.

56. Bieschke J. Natural compounds may open new routes to treatment of amyloid diseases. Neurotherapeutics. 2013;10:429-39. doi:10.1007/s13311013-0192-7.

57. Kennedy ME, Stamford AW, Chen X, Cox K, Cumming JN, Dockendorf MF, Egan M, Ereshefsky L, Hodgson RA, Hyde LA, Jhee S, Kleijn HJ, Kuvelkar R, Li W, Mattson BA, Mei H, Palcza J, Scott JD, Tanen M, Troyer MD, Tseng JL, Stone JA, Parker EM, Forman MS. The BACE1 inhibitor verubecestat (MK8931) reduces CNS $\beta$-amyloid in animal models and in Alzheimer's disease patients. Sci Transl Med. 2016;8(363):363ra. 150

58. Llorens-Marítin M, Jurado J, Hernández F, Avila J. GSK-3ß, a pivotal kinase in Alzheimer disease. Front Mol Neurosci. 2014;7:46.

59. Roy SM, Grum-Tokars VL, Schavocky JP, Saeed F, Staniszewski A, Teich AF, Arancio O, Bachstetter AD, Webster SJ, Van Eldik LJ, Minasov G, Anderson WF, Pelletier JC, Watterson DM. Targeting human central nervous system protein kinases: An isoform selective p38aMAPK inhibitor that attenuates disease progression in Alzheimer's disease mouse models. ACS Chem Neurosci. 2015;6(4):666-80. Epub 2015 Feb 23.

60. Min SW, Chen X, Tracy TE, Li Y, Zhou Y, Wang C, Shirakawa K, Minami SS, Defensor E, Mok SA, Sohn PD, Schilling B, Cong X, Ellerby L, Gibson BW, Johnson J, Krogan N, Shamloo M, Gestwicki J, Masliah E, Verdin E, Gan L. Critical role of acetylation in tau-mediated neurodegeneration and cognitive deficits. Nat Med. 2015;21(10):1154-62. doi:10.1038/nm.3951

61. Tebbenkamp AT, Borchelt DR. Analysis of chaperone mRNA expression in the adult mouse brain by meta analysis of the Allen Brain Atlas. PLoS One 2010;5(10), e13675. doi:10.1371/journal.pone.0013675.

62. Lindberg I, Shorter J, Wiseman RL, Chiti F, Dickey CA, McLean PJ. Chaperones in Neurodegeneration. J Neurosci. 2015;35:13853-9. doi:10. 1523/JNEUROSCI.2600-15.2015.

63. Carnemolla A, Lazell H, Moussaoui S, Bates GP. In Vivo Profiling Reveals a Competent Heat Shock Response in Adult Neurons: Implications for Neurodegenerative Disorders. PLoS One. 2015;10, e0131985. doi:10.1371/ journal.pone.0131985.

64. Vilarino-Guell C, Rajput A, Milnerwood AJ, Shah B, Szu-Tu C, Trinh J, Yu I, Encarnacion M, Munsie LN, Tapia L, Gustavsson EK, Chou P, Tatarnikov I, Evans DM, Pishotta FT, Volta M, Beccano-Kelly D, Thompson C, Lin MK, Sherman HE, Han HJ, Guenther BL, Wasserman WW, Bernard V, Ross CJ, Appel-Cresswell S, Stoessl AJ, Robinson CA, Dickson DW, Ross OA, Wszolek ZK, Aasly JO, Wu RM, Hentati F, Gibson RA, McPherson PS, Girard M, Rajput M, Rajput AH, Farrer MJ. DNAJC13 mutations in Parkinson disease. Hum Mol Genet. 2014;23:1794-801. doi:10.1093/hmg/ddt570.

65. Wadhwa R, Ryu J, Ahn HM, Saxena N, Chaudhary A, Yun CO, Kaul SC. Functional significance of point mutations in stress chaperone mortalin and their relevance to Parkinson disease. J Biol Chem. 2015;290:8447-56. doi:10. 1074/jbc.M114.627463.

66. Johnson JO, Mandrioli J, Benatar M, Abramzon Y, Van Deerlin VM, Trojanowski JQ, Gibbs JR, Brunetti M, Gronka S, Wuu J, Ding J, McCluskey L, Martinez-Lage M, Falcone D, Hernandez DG, Arepalli S, Chong S, Schymick JC, Rothstein J, Landi F, Wang YD, Calvo A, Mora G, Sabatelli M, Monsurrò MR, Battistini S, Salvi F, Spataro R, Sola P, Borghero G, Consortium ITALSGEN, Galassi G, Scholz SW, Taylor JP, Restagno G, Chiò A, Traynor BJ. Exome sequencing reveals VCP mutations as a cause of familial ALS. Neuron. 2010; 68:857-64. doi:10.1016/j.neuron.2010.11.036.

67. Smith HL, Li W, Cheetham ME. Molecular chaperones and neuronal proteostasis. Semin Cell Dev Biol. 2015;40:142-52. doi:10.1016/j.semcdb.2015.03.003.

68. Thirstrup K, Sotty F, Montezinho LC, Badolo L, Thougaard A, Kristjánsson M, Jensen T, Watson S, Nielsen SM. Linking HSP90 target occupancy to HSP70 induction and efficacy in mouse brain. Pharmacol Res. 2016;104:197-205. doi:10.1016/j.phrs.2015.12.028.

69. Brandvold KR, Morimoto RI. The Chemical Biology of Molecular Chaperones-Implications for Modulation of Proteostasis. J Mol Biol. 2015; 427:2931-47. doi:10.1016/j.jmb.2015.05.010.

70. Pratt WB, Gestwicki JE, Osawa Y, Lieberman AP. Targeting Hsp90/ Hsp70-based protein quality control for treatment of adult onset neurodegenerative diseases. Annu Rev Pharmacol Toxicol. 2015;55: 353-71. doi:10.1146/annurev-pharmtox-010814-124332. Epub 2014 Sep 25.

71. Bose S, Cho J. Targeting chaperones, heat shock factor-1, and unfolded protein response: Promising therapeutic approaches for neurodegenerative disorders. Mol Psychiatry. 2016. doi:10.1038/mp.2016.104.

72. Fontaine SN, Martin MD, Dickey CA. Neurodegeneration and the Heat Shock Protein 70 Machinery: Implications for Therapeutic Development. Curr Top Med Chem. 2016;16(25):2741-52

73. Wang B, Liu Y, Huang L, Chen J, Li JJ, Wang R, Kim E, Chen Y, Justicia C, Sakata K, Chen H, Planas A, Ostrom RS, Li W, Yang G, McDonald MP, Chen R, Heck DH, Liao FF. A CNS-permeable Hsp90 inhibitor rescues synaptic dysfunction and memory loss in APP-overexpressing Alzheimer's mouse model via an HSF1-mediated mechanism. Ageing Res Rev. 2016. doi:10. 1016/j.arr.2016.09.004.

74. Martin MD, Baker JD, Suntharalingam A, Nordhues BA, Shelton LB, Zheng D, Sabbagh JJ, Haystead TA, Gestwicki JE, Dickey CA. Inhibition of Both Hsp70 Activity and Tau Aggregation in Vitro Best Predicts Tau Lowering Activity of Small Molecules. ACS Chem Biol. 2016;11(7):2041-8. doi:10.1021/ acschembio.6b00223.

75. DeSantis ME, Leung EH, Sweeny EA, Jackrel ME, Cushman-Nick M, NeuhausFollini A, Vashist S, Sochor MA, Knight MN, Shorter J. Operational plasticity enables hsp104 to disaggregate diverse amyloid and nonamyloid clients. Cell. 2012;151(4):778-93. doi:10.1016/j.cell.2012.09.038.

76. Liu YH, Han YL, Song J, Wang Y, Jing YY, Shi Q, Tian C, Zang ZY, Li CP, Han J, Dong XP. Heat shock protein 104 inhibited the fibrillization of prion peptide 106-126 and disassembled prion peptide 106-126 fibrils in vitro. Int J Biochem Cell Biol. 2011;43(5):768-74. doi:10.1016/j.biocel.2011.01.022.

77. Jackrel ME, DeSantis ME, Martinez BA, Castellano LM, Stewart RM, Caldwell KA, Caldwell GA, Shorter J. Potentiated Hsp104 variants antagonize diverse proteotoxic misfolding events. Cell. 2014;156(1-2):170-82. doi:10.1016/j.cell. 2013.11.047.

78. Mack KL, Shorter J. Engineering and Evolution of Molecular Chaperones and Protein Disaggregases with Enhanced Activity. Front Mol Biosci. 2016;3:8. doi:10.3389/fmolb.2016.00008. eCollection 2016.

79. Ciechanover A, Kwon YT. Degradation of misfolded proteins in neurodegenerative diseases: therapeutic targets and strategies. Exp Mol Med. 2015;47, e147. doi:10.1038/emm.2014.117.

80. Dantuma NP, Bott LC. The ubiquitin-proteasome system in neurodegenerative diseases: precipitating factor, yet part of the solution. Front Mol Neurosci. 2014; 7:70. doi:10.3389/fnmol.2014.00070. eCollection 2014.

81. Cook C, Stetler C, Petrucelli L. Disruption of protein quality control in Parkinson's disease. Cold Spring Harb Perspect Med. 2012;2(5):a009423. doi:10.1101/cshperspect.a009423.

82. Moscovitz O, Ben-Nissan G, Fainer I, Pollack D, Mizrachi L, Sharon M. The Parkinson's-associated protein DJ-1 regulates the $20 \mathrm{~S}$ proteasome. Nat Commun. 2015:6:6609. doi:10.1038/ncomms7609.

83. Ebrahimi-Fakhari D, Cantuti-Castelvetri I, Fan Z, Rockenstein E, Masliah E, Hyman BT, McLean PJ, Unni VK. Distinct roles in vivo for the ubiquitinproteasome system and the autophagy-lysosomal pathway in the 
degradation of a-synuclein. J Neurosci. 2011;31(41):14508-20. doi:10.1523/ JNEUROSCI.1560-11.2011.

84. Opattova A, Cente M, Novak M, Filipcik P. The ubiquitin proteasome system as a potential therapeutic target for treatment of neurodegenerative diseases. Gen Physiol Biophys. 2015;34(4):337-52.

85. Lee JH, Shin SK, Jiang Y, Choi WH, Hong C, Kim DE, Lee MJ. Facilitated Tau Degradation by USP14 Aptamers via Enhanced Proteasome Activity. Sci Rep. 2015;5:10757. doi:10.1038/srep10757.

86. Rao G, Croft B, Teng C, Awasthi V. Ubiquitin-Proteasome System in Neurodegenerative Disorders. J Drug Metab Toxicol. 2015;6:187. doi:10.4172/ 2157-7609.1000187.

87. Harris $\mathrm{H}$, Rubinsztein DC. Control of autophagy as a therapy for neurodegenerative disease. Nat Rev Neurol. 2011;8(2):108-17. doi:10.1038/ nrneurol.2011.200.

88. Martinez-Vicente M. Autophagy in neurodegenerative diseases: From pathogenic dysfunction to therapeutic modulation. Semin Cell Dev Biol. 2015;40:115-26. doi:10.1016/.semcdb.2015.03.005.

89. Rousseau A, Bertolotti A. An evolutionarily conserved pathway controls proteasome homeostasis. Nature. 2016:536(7615):184-9.

90. Sasazawa Y, Sato N, Umezawa K, Simizu S. Conophylline protects cells in cellular models of neurodegenerative diseases by inducing mammalian target of rapamycin (mTOR)-independent autophagy. J Biol Chem. 2015; 290(10):6168-78. doi:10.1074/jbc.M114.606293.

91. Manzoni C, Mamais A, Roosen DA, Dihanich S, Soutar MP, Plun-Favreau H, Bandopadhyay R, Hardy J, Tooze SA, Cookson MR, Lewis PA. mTOR independent regulation of macroautophagy by Leucine Rich Repeat Kinase 2 via Beclin-1. Sci Rep. 2016;6:35106. doi:10.1038/srep35106.

92. Wisniewski T, Goni F. Immunotherapeutic approaches for Alzheimer's disease. Neuron. 2015;85(6):1162-76. doi:10.1016/.neuron.2014.12.064.

93. Genereux JC, Wiseman RL. Regulating extracellular proteostasis capacity through the unfolded protein response. Prion. 2015;9(1):10-21. doi:10.1080/ 19336896.2015.1011887.

94. Savage MJ, Kalinina J, Wolfe A, Tugusheva K, Korn R, Cash-Mason T, Maxwell JW, Hatcher NG, Haugabook SJ, Wu G, Howell BJ, Renger JJ, Shughrue PJ, McCampbell A. A sensitive abeta oligomer assay discriminates Alzheimer's and aged control cerebrospinal fluid. J Neurosci. 2014;34:2884-97. doi:10. 1523/JNEUROSCl.1675-13.2014.

95. De Genst E, Messer A, Dobson CM. Antibodies and protein misfolding: From structural research tools to therapeutic strategies. Biochim Biophys Acta. 1844:2014:1907-19. doi:10.1016/j.bbapap.2014.08.016.

96. Vaikath NN, Majbour NK, Paleologou KE, Ardah MT, van Dam E, van de Berg WD, Forrest SL, Parkkinen L, Gai WP, Hattori N, Takanashi M, Lee SJ, Mann DM, Imai Y, Halliday GM, Li JY, El-Agnaf OM. Generation and characterization of novel conformation-specific monoclonal antibodies for alpha-synuclein pathology. Neurobiol Dis. 2015;79:81-99. doi:10.1016/ j.nbd.2015.04.009.

97. Deane R, Bell RD, Sagare R, Zlokovic BV. Clearance of amyloid-beta peptide across the blood-brain barrier: implication for therapies in Alzheimer's disease. CNS Neurol Disord Drug Targets. 2009;8(1):16-30.

98. Watt AD, Crespi GA, Down RA, Ascher DB, Gunn A, Perez KA, McLean CA, Villemagne VL, Parker MW, Barnham KJ, Miles LA. Do current therapeutic anti-A $\beta$ antibodies for Alzheimer's disease engage the target? Acta Neuropathol. 2014;127(6):803-10. doi:10.1007/s00401-014-1290-2.

99. Bouter Y, Lopez Noguerola JS, Tucholla P, Crespi GA, Parker MW, Wiltfang J, Miles LA, Bayer TA. Abeta targets of the biosimilar antibodies of Bapineuzumab, Crenezumab, Solanezumab in comparison to an antibody against $\mathrm{N}$-truncated Abeta in sporadic Alzheimer disease cases and mouse models. Acta Neuropathol. 2015;130(5):713-29.

100. Fuller JP, Stavenhagen JB, Christensen S, Kartberg F, Glennie MJ, Teeling JL. Comparing the efficacy and neuroinflammatory potential of three antiabeta antibodies. Acta Neuropathol. 2015;130(5):699-711. doi:10.1007/ s00401-015-1484-2.

101. Crespi GA, Hermans SJ, Parker MW, Miles LA. Molecular basis for mid-region amyloid- $\beta$ capture by leading Alzheimer's disease immunotherapies. Sci Rep. 2015;5:9649. doi:10.1038/srep09649.

102. Cramer PE, Cirrito JR, Wesson DW, Lee CY, Karlo JC, Zinn AE, Casali BT, Restivo JL, Goebel WD, James MJ, Brunden KR, Wilson DA, Landreth GE. ApoE-directed therapeutics rapidly clear beta-amyloid and reverse deficits in AD mouse models. Science. 2012;335:1503-6. doi:10.1126/ science. 1217697.
103. Boehm-Cagan A, Michaelson D. M. Reversal of apoE4-driven brain pathology and behavioral deficits by bexarotene. J Neurosci. 2014;34:7293301. doi:10.1523/JNEUROSCI.5198-13.2014.

104. Vazquez-Lombardi R, Phan TG, Zimmermann C, Lowe D, Jermutus L, Christ D. Challenges and opportunities for non-antibody scaffold drugs. Drug Discov Today. 2015;20(10):1271-83. doi:10.1016/j.drudis.2015.09.004.

105. Iba M, Guo JL, McBride JD, Zhang B, Trojanowski JQ, Lee VM. Synthetic tau fibrils mediate transmission of neurofibrillary tangles in a transgenic mouse model of Alzheimer's-like tauopathy. J Neurosci. 2013;33:1024-37. doi:10. 1523/JNEUROSCI.2642-12.2013.

106. Kim E, Wang B, Sastry N, Masliah E, Nelson PT, Cai H, Liao FF. NEDD4mediated HSF1 degradation underlies a-synucleinopathy. Hum Mol Genet. 2016;25(2):211-22. doi:10.1093/hmg/ddv445.

107. Neef DW, Jaeger AM, Thiele DJ. Heat shock transcription factor 1 as a therapeutic target in neurodegenerative diseases. Nat Rev Drug Discov. 2011;10(12):930-44.

108. Verma P, Pfister JA, Mallick S, D'Mello SR. HSF1 protects neurons through a novel trimerization- and HSP-independent mechanism. J Neurosci. 2014; 34(5):1599-612. doi:10.1523/JNEUROSCI.3039-13.2014.

109. Kondo N, Katsuno M, Adachi H, Minamiyama M, Doi H, Matsumoto S, Miyazaki Y, lida M, Tohnai G, Nakatsuji H, Ishigaki S, Fujioka Y, Watanabe H, Tanaka F, Nakai A, Sobue G. Heat shock factor-1 influences pathological lesion distribution of polyglutamine-induced neurodegeneration. Nat Commun. 2013;4:1405. doi:10.1038/ncomms2417.

110. Bersuker K, Hipp MS, Calamini B, Morimoto RI, Kopito RR. Heat shock response activation exacerbates inclusion body formation in a cellular model of Huntington disease. J Biol Chem. 2013;288:23633-8. doi:10.1074/ jbc.C113.481945.

111. Lamech LT, Haynes CM. The unpredictability of prolonged activation of stress response pathways. J Cell Biol. 2015;209(6):781-7. doi:10.1083/jcb. 201503107

112. Labbadia J, Cunliffe H, Weiss A, Katsyuba E, Sathasivam K, Seredenina T, Woodman B, Moussaoui S, Frentzel S, Luthi-Carter R, Paganetti P, Bates GP. Altered chromatin architecture underlies progressive impairment of the heat shock response in mouse models of Huntington disease. J Clin Invest. 2011;121:3306-19. doi:10.1172/JCI57413.

113. Mendillo ML, Santagata S, Koeva M, Bell GW, Hu R, Tamimi RM, Fraenkel E, Ince TA, Whitesell L, Lindquist S. HSF1 drives a transcriptional program distinct from heat shock to support highly malignant human cancers. Cell. 2012;150(3):549-62. doi:10.1016/j.cell.2012.06.031.

114. Jaeger AM, Pemble CW, Sistoen L, Thiele DJ. Structures of HSF2 Reveal Mechanisms for Differential Regulation of Human Heat Shock Factors. Nat Struct Mol Biol. 2016;23(2):147-54. doi:10.1038/nsmb.3150.

115. Shineman DW, Basi GS, Bizon JL, Colton CA, Greenberg BD, Hollister BA, Lincecum J, Leblanc GG, Lee LB, Luo F, Morgan D, Morse I, Refolo LM, Riddell DR, Scearce-Levie K, Sweeney P, Yrjänheikki J, Fillit HM. Accelerating drug discovery for Alzheimer's disease: best practices for preclinical animal studies. Alzheimers Res Ther. 2011;3:28. doi:10.1186/alzrt90.

116. Karran E, Hardy J. A critique of the drug discovery and phase 3 clinical programs targeting the amyloid hypothesis for Alzheimer disease. Ann Neurol. 2014;76:185-205. doi:10.1002/ana.24188.

117. Sperling R, Mormino E, Johnson K. The evolution of preclinical Alzheimer's disease: implications for prevention trials. Neuron. 2014;84:608-22. doi:10. 1016/j.neuron.2014.10.038.

118. Langfelder P, Cantle JP, Chatzopoulou D, Wang N, Gao F, Al-Ramahi I, Lu XH, Ramos EM, El-Zein K, Zhao Y, Deverasetty S, Tebbe A, Schaab C, Lavery DJ, Howland D, Kwak S, Botas J, Aaronson JS, Rosinski J, Coppola G, Horvath $S$, Yang XW. Integrated genomics and proteomics define huntingtin CAG length-dependent networks in mice. Nat Neurosci. 2016;19(4):623-33. doi: 10.1038/nn.4256.

119. Yamanaka $T$, Tosaki A, Miyazaki $H$, Kurosawa $M$, Koike $M$, Uchiyama $Y$, Maity SN, Misawa H, Takahashi R, Shimogori T, Hattori N, Nukina N. Differential roles of NF-Y transcription factor in ER chaperone expression and neuronal maintenance in the CNS. Sci Rep. 2016;6: 34575. doi:10.1038/srep34575.

120. Cavanaugh SE, Pippin JJ, Barnard ND. Animal models of Alzheimer disease: historical pitfalls and a path forward. ALTEX. 2014;31(3):279-302. http://dX. doi.org/10.14573/altex.1310071.

121. Benraiss A, Wang S, Herrlinger S, Li X, Chandler-Militello D, Mauceri J, Burm HB, Toner M, Osipovitch M, Jim Xu Q, Ding F, Wang F, Kang N, Kang J, Curtin PC, Brunner D, Windrem MS, Munoz-Sanjuan I, Nedergaard M, 
Goldman SA. Human glia can both induce and rescue aspects of disease phenotype in Huntington disease. Nat Commun. 2016;7:11758. doi:10.1038/ ncomms11758.

122. Thompson AG, Gray E, Heman-Ackah SM, Mäger I, Talbot K, Andaloussi SE, Wood MJ, Turner MR. Extracellular vesicles in neurodegenerative disease pathogenesis to biomarkers. Nat Rev Neurol. 2016;12(6):346-57. doi:10.1038/ nrneurol.2016.68.

123. Catafau AM, Bullich S. Non-amyloid PET imaging biomarkers for neurodegeneration: Focus on tau, alpha-synuclein and neuroinflamation. Curr Alzheimer Res. 2016. [Epub ahead of print].

124. Saint-Aubert L, Lemoine L, Chiotis K, Leuzy A, Rodriguez-Vieitez E, Nordberg A. Tau PET imaging: present and future directions. Mol Neurodegener. 2017; 12(1):19. doi:10.1186/s13024-017-0162-3.

125. Villemagne VL, Doré V, Bourgeat P, Burnham SC, Laws S, Salvado O, Masters CL, Rowe CC. Aß-amyloid and Tau Imaging in Dementia. Semin Nucl Med. 2017; 47(1):75-88. doi:10.1053/j.semnuclmed.2016.09.006.

126. Sehlin D, Fang XT, Cato L, Antoni G, Lannfelt L, Syvänen S. Antibody-based PET imaging of amyloid beta in mouse models of Alzheimer's disease. Nat Commun. 2016;7:10759. doi:10.1038/ncomms10759.

127. Finneman SJ, Nabulsi NB, Eid T, Detyniecki K, Lin S, Chen M, Dhaher R, Matuskey D, Baum E, Holden D, Spencer DD, Mercier K, Hannestad J, Huang Y, Carson RE. Imaging synaptic density in the living human brain. Sci Transl Med. 2016;8(348):348ra96. doi:10.1126/scitransImed.aaf6667.

128. Morris M, Sanchez PE, Verret L, Beagle AJ, Guo W, Dubal D, Ranasinghe KG, Koyama A, Ho K, Yu GQ, Vossel KA, Mucke L. Network dysfunction in asynuclein transgenic mice and human Lewy body dementia. Ann Clin Transl Neurol. 2015;2(11):1012-28. doi:10.1002/acn3.257.

129. Sorg C, Göttler J, Zimmer C. Imaging Neurodegeneration: Steps Toward Brain Network-Based Pathophysiology and Its Potential for Multi-modal Imaging Diagnostics. Clin Neuroradiol. 2015;25 Suppl 2:177-81. doi:10.1007/ s00062-015-0438-3.

\section{Submit your next manuscript to BioMed Central and we will help you at every step:}

- We accept pre-submission inquiries

- Our selector tool helps you to find the most relevant journal

- We provide round the clock customer support

- Convenient online submission

- Thorough peer review

- Inclusion in PubMed and all major indexing services

- Maximum visibility for your research

Submit your manuscript at www.biomedcentral.com/submit 